\title{
BOARD CAPITAL EFFECT ON FIRM PERFORMANCE: EVIDENCE FROM INDONESIA
}

\author{
Maria Kontesa* \\ Tanjungpura University \\ Widya Dharma Pontianak University \\ Andreas Lako \\ Soegijapranata Catholic University \\ Wendy \\ Tanjungpura University
}

\begin{abstract}
Human capital effects have been ignored as important resources to induce the organization's performance in firm-level research. The proponents of human capital theory and resource-based view theory argue that the human resources attached to each board member, such as networking, education, and experience, might induce the performance. Yet, agency theory argues those strategic resources might bring higher transaction costs and entrenchment costs. Therefore, this study aims to examine the board's capital effect on firm performance for a sample of 252 listed firms in Indonesia over 2011-2017. Using dynamic GMM panel regression, we confirm the hypothesis about board capital and performance. The results imply that board members' networking and experience are two important factors for firm performance. However, boar members' education does not give any impact. It confirms prior theories whereby the capability and competency of directors are an important source for the firm to achieve its objective. Networking and experience might help the firm to avoid financial distress. It furthers implies that shareholders should choose board members with a high level of networking and experience, not education.
\end{abstract}

Keywords: Director capital; Social capital; Director networking; Director education; Director experience; Firm performance

Received: 30 August 2029

Accepted: 21 February 2020

\section{INTRODUCTION}

Does director competency affect firm performance? Surprisingly, little is known about the answer to this question as it is rarely found empirical research on the association between director competency and firm performance. Recent regulatory activity is more on the increase of director compensation and its margin towards firm performance as the consideration for good governance practice (e.g. Sarbanes-Oxley Act of 2002). Much research emphasizes more on the agency cost by omitting the fair compensation, and its role in ethical governance. This is quite intriguing considering many empirical findings support the notion that expertise of agents (directors) may

\footnotetext{
* Corresponding author: Maria Kontesa, doctoral candidate Faculty of Economics and Business, Tanjungpura University, Pontianak \& Lecturer Widya Dharma Pontianak University. Email:mariakontesa80@yahoo.com
} 
improve governance monitoring and lessen the agency cost (Karamanou \&Vafeas, 2005; Defond, Hann, \& Hu, 2005). More generally, Becker (1964) suggests the productivity of agents (directors) depends on a broad range of attributes that comprise their human and social capital. Yet, this notion is somehow forgotten, and literature heavily evaluates the incentive issues.

Interestingly, theories in strategic management and finance area have implied the link between director capital and firm performance. For instance, there is a resource-based view theory that provides a conceptual tool in understanding how knowledge, experience, and networks of directors are important capital for a firm's operation (Hillman \& Dalziel 2003; Haynes \& Hillman 2010). Meanwhile, agency theory portrays board capital as the resource of agents (directors) to achieve the goal of firms leading to low agency costs (Lang \& Lang, 1988; Demerjian, Lev, Lewis $\&$ McVay; 2013; Cao, Myers, Myers, \& Omer, 2015). Thus far most of the existing literature does not contest these two big theories. If any, the findings are based on advanced markets, and little is known about the director's capital effect on a firm's performance from developing markets. Reasonably, the developing market may offer a different snapshot of the relationship between board capital and firm performance due to its unique institutional setting compared to developed markets. In other words, the relative benefit of board capital for firms in developing markets may not necessarily at the same magnitude with developed markets. Building on these theoretical assumptions, we aim to empirically investigate how board capital may influence the performance of firms in a relatively less developed market like Indonesia.

In the world of a highly competitive top executive - labor market, there should be positive impacts of board capital as a result of talent embodiment. However, talent pooling may not necessarily carry better performance because running an organization is also about intuition and other external factors (e.g. Khatri \& Ng, 2000; Gregg, 2006; Sheng et al, 2011; Bandyopadhyay \& Barua, 2016). With no exception, directors in Indonesia are also a pool of good talents as the consequence of its open economy since the 1980s. It is reported that there are 43,816 expatriate in Indonesia per 2016, and there were 3.6 million Indonesian pursued bachelor degree abroad ${ }^{2}$ in 2010 . This is huge compared to the number of 2 million Indonesia studied abroad in 2000. Yet, having good capital does not guarantee great performance.

Indonesia offers a unique environment for examining the relationship between board capital and firm performance for numerous reasons. First, the gap in educational level among Indonesian would act as a good platform for further exploration of this topic. This is not to mention that by far there is no Indonesian university in the top 200 world universities. Graduating from a local university might give a different impact compared to graduating from abroad. Second, Indonesia provides an interesting institutional setting to examine the effect of board capital on firm performance with its less developed economy, and governance monitoring is low. Claessens et al (2002) and Leuz et al (2006) argue that networking and cronyism as the outcome from the business group and political connection may play an important role in enhancing the firm's performance. Thirdly, the prevalence of external factors and high economic cost may create inefficiency markets leading to a wasted resource of director capital. No matter how big is the capital, but the inefficient

\footnotetext{
${ }^{1}$ As reported inhttp://www.expat.or.id/info/howmanyexpatsinindonesia.html

${ }^{2}$ See http://www.thejakartapost.com/news/2014/01/11/high-time-internationalization-indonesian-higher-learning.html
} 
market, either due to bribery, red tape, unhealthy competition, or a high transaction cost, makes the director capital as unutilized resource contesting the resource-based view theory.

Our research is built under two big theories: resource-based view and agency theory. Resourcebased view proponents such as Hilman and Daziel (2003) argue that board capital refers to a board's ability to provide strategic decision making. The capital is a competitive resource for firms, and enable directors to act as a resource to management by providing advice and counsel. Meanwhile, agency theory explains that capital is a strategic tool of directors to be chosen by owners to run the firms. This capital may distinguish the directors from their peers, and this benefits the owners by having better resources and low agency costs. Jeremias and Gani (2014) report the positive impact of board capital on firm performance.

Additionally, Hillman and Dalziel (2003) empirically investigated the association and found that the provision of resources and monitoring of the business operation was directly related to board capital. The elements of experience, expertise, and networking determine the efficiency and effectiveness in facilitating the provision of resources, and also facilitate the monitoring. Hence, this situation led to the unfavorable performance of the firms.

According to Haynes and Hillman (2010), the business performs well and badly depends on the board's capital because strategic change is closely related to the competency of directors. The use of right and wrong strategy is relying on how much the education, experience and how professional the boards have. Iskandar, Noor, and Omar (2012) also had a consistent result with other researchers that they empirically investigated the financial distress and characteristics of the board of directors. They stated that the firm confronted with financial distress was because of the lack of monitoring and independent control over the management. The member of the board of directors is qualified with the sufficient knowledge, and experience in finance will enhance the skill of monitoring and controlling of the board on business management (Iskandar et al., 2012). Conversely, insufficient knowledge and experience in finance lead to the firm confronted with financial distress. Hence, we hypothesize: Higher board capital leads to better firm 's performance.

In sum, our research objective is to examine the role of board capital on a firm's performance. We expect to draw a contention about the resource-based view and agency theory. We replicate Reeb and Zhao (2013) in constructing our director capital by slightly modification to tune in the Indonesian context. We also follow previously established studies by controlling the performance with certain firm characteristics. For robustness reason, we omit the endogeneity issue by employing panel GMM regression fixed effects and control the standard error by using the white test to rectify heteroscedasticity and autocorrelation.

Our study contributes in three ways. First, we add to the literature by a comprehensive understanding of the link between board capital and firm performance. Second, we document the empirical findings of this research area of developing markets such as Indonesia. Third, we further establish the fact that resource-based view theory and agency theory can be utilized to explain the association between board capital and firm performance. Investors or owners may look at this matter as the consideration factors of picking a director for their firm. The rest of this paper is organized as follows: Section 2 describes the data and methodology. Section 3 reports the results and elaborates on the findings. Section 4 is for the conclusion. 


\section{DATA AND RESEARCH DESIGN}

\subsection{Data}

This research uses all non-financial industry firms. We also exclude the utility industry from our sample. The reason is that the financial industry and utility industry have different nature of business due to its strategic market in Indonesia. Moreover, these two industries have different business activities in monitoring and guiding the firm operation. Therefore, adding these two industries may give bias estimation. We exclude all firms with unavailable information and retrieve all financial data from the annual report, and also including the board capital over 7-year observations (2011-2017) for 252 listed firms with 1764 pooled year-firm observations. To confirm certain data of board capital, we use Linkedin, RelSci and Bloomberg database. The detail is reported in the next section.

\subsection{Estimation Models}

This research aims to examine the relationship between the board capital and firm's performance. To achieve that objective, the estimation model is firstly constructed based on the baseline model in firm's performance research. Corporate finance literature reports that common determinants of firm's performance are firm size (SIZE), firm leverage (DEBT), and firm age (AGE). This is following the economies of scale hypothesis in many corporate finance papers such as Hall and Weiss (1967), Thornhill and Amit (2003), Hillman et al (2009), and Ung et al (2016)

The measurement of firm size is the natural logarithm of total assets of the firm, and firm age is measured by natural logarithms of the cumulative years of the firm since establishment. For firm leverage, we follow Hribar and Nichols (2007), which is measured by ratio of debt to equity. These variables in the baseline model is treated as the control variables of the model. Yet, we have two measures of firm's performance: accounting based performance and market based performance. Our accounting based performance uses Return on Assets (ROA) as the proxy. Meanwhile, Tobin's $\mathrm{Q}(\mathrm{Q})$ is the proxy for market based performance. Then, we introduce board capital variable $(B C A P I T A L, t)$ into the baseline model, and estimate it as follow:

Performance $_{i, t}=\beta_{0}+\beta_{1}$ SIZE $_{i, t}+\beta_{2} D E B T_{i, t}+\beta_{3} A G E_{i, t}+\beta_{4} B C A P I T A L_{i, t}+\varepsilon_{i, t} \ldots \ldots \ldots \ldots \ldots \ldots \ldots$ (1)

Where Performance ${ }_{i, t}$ is firm's performance i at year $\mathrm{t} ; S I Z E_{i, t}$ is firm size for firm i at year t; $D E B T_{i, t}$ is firm leverage for firm $\mathrm{i}$ at year $\mathrm{t} ; A G E_{i, t}$ is firm age for firm $\mathrm{i}$ at year $\mathrm{t} ; \varepsilon_{i, t}$ is error term for firm $\mathrm{i}$ at year $\mathrm{t}$; and $\beta_{0}$ is unknown parameter which held at constant. It is noteworthy that board capital consists of networking, education, and experience. It is important to reveal which board capital dimension may affect the firm's performance. Therefore, estimation Model(1) is further examined by modifying the board capital to its sub-dimension. Therefore, the board capital variable is replaced by networking, education, and experience. The estimation model is as follow:

$$
\begin{aligned}
\text { Performance }_{i, t}=\beta_{0} & +\beta_{1} \text { SIZE }_{i, t}+\beta_{2} \text { DEBT }_{i, t}+\beta_{3} A G E_{i, t}+\beta_{4} \text { NETWORKING }_{i, t} \\
& +B_{5} \text { EDUCATION }_{i, t}+\beta_{6} \text { EXPERIENCE }_{i, t}+\varepsilon_{i, t} \ldots \ldots \ldots \ldots \ldots
\end{aligned}
$$

We argue that endogeneity issue may incur in our estimation model. Therefore, we run panel GMM model to tackle the issue by following Wintoki et al (2012). This model specification uses lagged 
levels as instruments for the regression in differences and lagged differences as instruments for the regression in levels. It also includes firm-specific effect $\left(\alpha_{i}\right)$ to control for all unobserved timevariant determinants of performance at the firm level that are constant over the sample period. The model also includes a time-specific effect $\left(\sigma_{t}\right)$ to control for aggregate changes that could affect the demand for firm performance. Our final model specification is as follow:

Performance $_{i, t}=\beta_{0}+\beta_{1}$ Performance $_{i, t}+\beta_{2}$ SIZE $_{i, t}+\beta_{3} D E B T_{i, t}+\beta_{4} A G E_{i, t}+\beta_{5} B_{C A P I T A L_{i, t}}+$ $\varepsilon_{i, t} \ldots \ldots \ldots \ldots \ldots \ldots \ldots$

and,

Performance $_{i, t}=\beta_{0}+\beta_{1}$ Performance $_{i, t}+\beta_{2}$ SIZE $_{i, t}+\beta_{3} D E B T_{i, t}+\beta_{4} A G E_{i, t}+\beta_{5} N E T W O R K I N G_{i, t}$

$+B_{6} E_{D U C A T I O N} N_{i, t}+\beta_{7} E_{\text {XPERIENCE }}, t+\varepsilon_{i, t} \ldots \ldots \ldots \ldots \ldots \ldots \ldots \ldots \ldots \ldots$ (4)

\subsection{Measuring Board Capital}

We follow the method of Reeb and Zhao (2013) in constructing the board capital with slight modification following Brahmana et al (2019). For example, we omit information related to CEO duality because CEO duality is not applicable for Indonesia context. We also modified the items of national-level professional affiliations and national-honors (Sir/Lord) by omitting it due to concomitant variation issue. Meanwhile, the educational measurement in Reeb and Zhao (2013) may not applicable for Indonesia context. We also modified this educational measure.

The calculation procedure of board capital emphasizes on averaging and ranking. The scoring items are shown in Table 1. Board capital value is the average from networking, education, and experience values. Therefore, it is important to calculate the mean value for networking, education, and experience. The procedure is as follow:

First, we calculate the value for each item as stated in Table 1. For example, item no.1 of networking capital is "Total current number of boards a director sits on during a given year". We count how many directors sit in a particular company in a particular year. We did this procedure for other items.

Table 1: Board Capital Matrix

\begin{tabular}{lll}
\hline \hline \multicolumn{3}{c}{ Develop Indices to Form a Composite Measure of Total Board Capital } \\
\hline Networking or Social of the Board & Educational of the Board & Experience Capital of the Board \\
\hline $\begin{array}{l}\text { 1. Total current number of boards a } \\
\text { director sits on during a given year. }\end{array}$ & $\begin{array}{l}\text { 1. Total number of director } \\
\text { that obtain bachelor's } \\
\text { degree, master's degree, law } \\
\text { degree or medical degree, as } \\
\text { well as a PhD degree. }\end{array}$ & $\begin{array}{l}\text { 1. Working history: the number } \\
\text { of directors who have } \\
\text { been a partner in a law firm; have } \\
\text { investment bank/venture capital } \\
\text { firm expertise; management } \\
\text { consulting experience; accounting } \\
\text { firm expertise; academic } \\
\text { experience. }\end{array}$ \\
& & $\begin{array}{l}\text { 2. Director information on } \\
\text { professional certification such as }\end{array}$ \\
\hline $\begin{array}{l}\text { 2. Total current number of nonprofit } \\
\text { boards a director sits on }\end{array}$ & & \\
\hline
\end{tabular}




\begin{tabular}{|c|c|c|}
\hline \multicolumn{3}{|c|}{ Develop Indices to Form a Composite Measure of Total Board Capital } \\
\hline Networking or Social of the Board & Educational of the Board & Experience Capital of the Board \\
\hline & & $\begin{array}{l}\text { CPA, CFA or certified fraud } \\
\text { examiner. }\end{array}$ \\
\hline $\begin{array}{l}\text { 3. Total number of corporate board } \\
\text { memberships / the total number of } \\
\text { commissioners }\end{array}$ & & $\begin{array}{l}\text { 3. Number of positions higher } \\
\text { than vice president } \\
\text { (Chemmanur\&Paeglis, 2005) that } \\
\text { directors have held during their } \\
\text { lifetime. }\end{array}$ \\
\hline $\begin{array}{l}\text { 4. Number of non-profit boards that } \\
\text { a director has served on in the past } \\
\text { but is no longer a current member / } \\
\text { the total number of independent } \\
\text { commissioners }\end{array}$ & & $\begin{array}{l}\text { 4. count the number of firms with } \\
\text { which the directors have worked } \\
\text { during their lifetime. }\end{array}$ \\
\hline $\begin{array}{l}\text { 5. Any current or prior government } \\
\text { position }\end{array}$ & & $\begin{array}{l}\text { 5. Others potential director } \\
\text { characteristic such as national- } \\
\text { level honours and awards and } \\
\text { membership in professional or } \\
\text { industrial association affiliations. }\end{array}$ \\
\hline $\begin{array}{l}\text { 6. Capture director information on } \\
\text { government board service which is } \\
\text { nominated by government agents. }\end{array}$ & & \\
\hline
\end{tabular}

Sources: Adopted from Reeb and Zhao (2013)

Second, to avoid the data variance issue, we rank each item score year-by-year. To do the rank, we made five groups where the lowest $20^{\text {th }}$ percentile group will be score 1 , and the highest $20^{\text {th }}$ percentile group will be score 5 . For example, if the lowest $20^{\text {th }}$ percentile is $0-5$, and the value of item no. 1 is 4 , hence, we give score " 1 ". If the second lowest $20^{\text {th }}$ percentile group is $6-10$, and the value of item no. 1 for company B in 2013 is 7, hence, we give score " 2 ". We did this procedure to all items of each company every period.

Third, we calculate the mean value of each dimension (networking, education, and experience) by taking the average value from total score. For example, if item no.1, 2, 3, 4, 5, and 6 of networking for company $\mathrm{A}$ in 2013 have score of 3, 3, 4, 4, 5, and 4, respectively, the mean value of networking will be $3.83(3+3+4+4+5+4=23,23 \div 6$ items $)$. We did this procedure to all dimensions of each company every period. Hence, each dimension from each firm in a particular year has an average value.

It is noteworthy that based on the Reeb and Zhao (2013) study, every education level is represented by a number from 1 to 7 , while this study uses 1 to 9 to represent the level of education of the board. The higher the education level, the higher the number represents. The indicators of the numbers by using the categorical variables method to represent the level of education such as 1 . Below the bachelor's degree; 2. Bachelor degree; 3. MBA degree; 4. Master degree; 5. Doctoral degree; 7. Top 200 bachelor degrees, according to QS University ranking; 8. Top 200 master degrees, according to QS University ranking; and 9. Top 200 doctoral degrees, according to QS University ranking. However, the scoring procedure remains the same. 


\section{RESULTS AND DISCUSSION}

\subsection{Descriptive Statistics}

Table 2 shows the descriptive statistics of the variables used in this study. It reports three important facts about our data set. Firstly, our data covers listed firms with average total assets of around 8.250 million dollars. This is good as a representation of listed firms in Indonesia. In regards to age, we cover most of the firms from relatively new firm to 109 -year firm. This is good to find out how age may play a significant role in firm performance.

Table 2 also reports the raw data of board capital. As earlier mentioned in our methodology section, we broke down the capital into the smallest dimensions, converted into a Likert scale under quartile, and later took the mean value. As portrayed in the table, there is a huge gap among Indonesian listed firms concerning the capital. The mean values are much lower than the median (the median value is 3 ), where several companies are falling into 4-Likert value and 5-Likert value implying their comparative advantage for board capital. Interestingly, our table also reports that for education matters, all of the directors have formal education as the minimum value is 1 .

The last facts are related to our data set for analysis matter. The performance of Indonesian listed firms are averagely 0.0285 for ROA, and 0.0199 for Tobin's Q through all firms, years, and industry. Meanwhile, our board capital value is the average of those three board capital dimensions: networking, education, and experience. Averagely, the board's capital value is 1.5120 . Meanwhile, the median is 1.42. This tells us that the averagely firm in Indonesia has a low level of board capital. In terms of sub-dimensions, Table 2 shows that the networking capital of Indonesian firms has an average value of 2.0234. It is the highest among all board capital dimensions. Meanwhile, education and experience have a mean value of 1.3161 and 1.1957.

Table 2: Descriptive Statistics

\begin{tabular}{lccc}
\hline \hline Variable & Mean & Median & Std. Dev. \\
\hline Dependent Variable & & & \\
ROA & 0.0285 & 0.0320 & 0.3254 \\
Q & 0.0199 & 0.1568 & 10.6713 \\
Main Effect & & & \\
Networking & 2.0234 & 1.8125 & 0.8941 \\
Education & 1.3161 & 1.2500 & 0.6516 \\
Experience & 1.1957 & 1.0000 & 0.8404 \\
BC & 1.5120 & 1.4200 & 0.6536 \\
Control Variable & & & \\
DEBT & 1.3323 & 0.8436 & 4.7321 \\
SIZE (LOG) & 21.4689 & 21.5756 & 1.8004 \\
AGE (YEARS) & 32.8768 & 32.0000 & 15.3048 \\
\hline \hline
\end{tabular}




\subsection{Correlation Analysis}

Table 3 shows the Pearson correlation coefficient among the variables. It documents their important findings. First, our performance measures are positively correlated. This confirms our rationale that accounting book performance (ROA) may measure similar to market-based performance (Tobin's Q). The coefficient correlation is 0.4579 indicating a mediocre magnitude among those performance variables.

Yet, the performance measures have a similar conclusion in regards to correlation analysis. The only difference is on the significant level. ROA is significantly correlated with the firm's size at a $1 \%$ level, meanwhile, Tobin's Q only correlated at the $10 \%$ level. ROA is significantly correlated with the firm's age at a 5\% level, meanwhile, Tobin's Q is at a $1 \%$ level. But both performance measures are significantly correlated with the board capital with the value of 0.1051 and 0.1332 for ROA and Tobin's Q, respectively.

For the sub-dimension of board capital, it has interesting results. First, ROA has a significant association with all its dimensions (networking, education, and experience). However, all the associations with its dimensions are positive with small coefficient values (less than 0.3). It means that there is a low magnitude of the correlation between ROA and board capital sub-dimensions (networking, education, and experience). The correlation results between Tobin's Q and the three sub-dimension are also varied. For instance, only networking has a significant association with Tobin's Q with a coefficient value of 0.366. Meanwhile, education and experience have no significant association with Tobin's Q.

Table 3:Correlation Matrix

\begin{tabular}{|c|c|c|c|c|c|c|c|c|c|}
\hline & 1 & 2 & 3 & 4 & 5 & 6 & 7 & 8 & 9 \\
\hline $1 \therefore \mathrm{Q}$ & 1 & & & & & & & & \\
\hline 2. Roa & 0.4579 & 1 & & & & & & & \\
\hline 3. Network & $0.366^{* * *}$ & $0.1379 * *$ & 1 & & & & & & \\
\hline 4. Edu & 0.0023 & $0.0818^{*}$ & $0.6514^{*}$ & 1 & & & & & \\
\hline 5. Exp & 0.0835 & $0.0726^{*}$ & $0.4762 *$ & $0.4022 *$ & 1 & & & & \\
\hline 6. $\mathrm{Bc}$ & $0.1332 * *$ & $0.1051 * * *$ & $0.8766^{*}$ & $0.8018^{*}$ & $0.7791 *$ & 1 & & & \\
\hline 7. Lev & 0.0042 & -0.0213 & -0.004 & 0.0159 & 0.0011 & 0.0041 & 1 & & \\
\hline 8. Size & $0.0106^{*}$ & $0.1356^{* *}$ & $0.5738^{*}$ & $0.4845^{*}$ & $0.3469^{*}$ & $0.5714 *$ & $0.0555^{*}$ & 1 & \\
\hline 9.Age & $0.326^{* * *}$ & $0.0834 *$ & $0.2225^{*}$ & $0.1166^{*}$ & 0.0446 & $0.1593 *$ & -0.0246 & 0.1470 * & 1 \\
\hline
\end{tabular}

\subsection{Results and Discussion}

We estimate model (1) and model (2) to reveal the board's capital effect on firm performance. The results are shown in Table 4, where it consists of four estimation results. The first and third are the baseline model. The second is the full model from the estimation model (2) with ROA. The last row is the estimation model (2) with Tobin's Q as the dependent variable. Even though the baseline model is important, but it is not our main objective. Therefore, we only discuss the full model as part of our analysis. The estimates in Table 4 are retrieved by employing a dynamic GMM method to rectify the endogeneity issue. The diagnostic tests also behave properly where AR(1) is expected 
to be significant, but not for AR(2). The Hansen test was also employed and is expected to have a p-value higher than 0.05. Overall, our GMM estimations are acceptable and there is no overidentification problem.

Table 4 reports that the higher the board capital, the better the performance is. The coefficient value is 0.7090 and 0.0566 for ROA and Tobin's Q respectively. This means that a firm with higher board capital might have better performance. These findings confirm the human capital theory and resource-based view theory where human capital is a strategic resource for an organization. The findings are in line with the result of Hillman and Dalziel (2003), Rose (2007), and Brahmana et al (2019) who pointed out that the positive effect of board capital on firm performance.

Table 4: Board Capital and Performance Results

\begin{tabular}{lcccc}
\hline \hline & \multicolumn{2}{c}{ ROA } & \multicolumn{2}{c}{ Q } \\
\hline Lag(1) & Baseline & Full Model & Baseline & Full Model \\
& -0.0038 & -0.0039 & -0.0319 & -0.0516 \\
BCapital & $(0.0113)$ & $(0.0113)$ & $(0.0376)$ & $(0.0375)$ \\
& & $0.7090^{* * *}$ & & $0.0566^{* *}$ \\
Debt & & $(0.1570)$ & & $(0.0268)$ \\
& $0.0296^{* * *}$ & $0.0296^{* * *}$ & 0.0189 & 0.0185 \\
Size & $(0.0110)$ & $(0.0110)$ & $(0.0400)$ & $(0.0199)$ \\
& $0.4440^{* * *}$ & $0.4381^{* * *}$ & $3.0907 * * *$ & $3.1381^{* * *}$ \\
Age & $(0.1257)$ & $(0.1265)$ & $(0.7482)$ & $(0.6003)$ \\
& $0.3606^{* * *}$ & $0.3599 * * *$ & $0.2446^{* *}$ & $0.2495^{* *}$ \\
Constant & $(0.0672)$ & $(0.0672)$ & $(0.1244)$ & $(0.1247)$ \\
& 0.2669 & 0.265 & $2.8488^{* * *}$ & $2.8365^{* * *}$ \\
\hline Industry-level & $(0.2524)$ & $(0.2525)$ & $(0.9166)$ & $(0.9165)$ \\
Control & & & & Yes \\
Cluster Standard & Yes & Yes & & Yes \\
Errors & Yes & Yes & Yes & Yes \\
AR(1) & $-2.718^{* * *}$ & $-2.894 * * *$ & $-2.272^{* *}$ & $-2.655^{* * *}$ \\
AR(2) & 1.46 & 1.22 & 1.09 & 1.36 \\
Hansen & 0.103 & 0.112 & 0.075 & 0.084 \\
\hline \hline
\end{tabular}

Note: The coefficient values are stated in figures while the standard errors are stated in The figures of parentheses. ***, $* *$ and $*$ denotes the level of significances of $1 \%, 5 \%$ and $10 \%$ respectively.

We estimate model (2) by introducing a more detail measure of board capital. The models were run under the GMM method to rectify the endogeneity issue. The standard errors were controlled under White's test to rectify the issue of heteroscedasticity and autocorrelation. The AR(2) and Hansen test results surmise that our GMM model is rigor and no over-identification problem. The findings are reported in Table 5.

This model estimates the association between Board Capital and Firm Performance, where the performance is measured by using Return on Assets (ROA) and Tobin's Q. The main effects are Networking, Education, and Experience, which are the sub-dimension of Board Capital. The regression was performed under dynamic GMM panel regression controlling industrial effect while 
controlling also for the Heteroskedasticity and Autocorrelation problems. Period of data ranges from 2011 to 2017.

Table 5 shows that networking has a significant effect on firm performance. The coefficient values were 2.0939 and 0.8858 for ROA and Tobin's Q model respectively. It implies that a firm that hired board members with a high level of networking might have increased performance. However, the educational background and experience of board members seem not to have any impact on firm performance. Hiring highly educated board members and or highly experienced board members will not give any impact on firm performance. This is in-line with previous research such as Serra et al (2016), Morresi (2017), Kagzi and Guha (2018), and Rossoni et al (2018).

Table 5: Board Capital and Performance - Sub-Sampling

\begin{tabular}{lcc}
\hline \hline & ROA & $\mathrm{Q}$ \\
\hline LAG(-1) & $0.3943^{* * *}$ & -0.0079 \\
NETWORKING & $(0.1339)$ & $(0.4044)$ \\
EDUCATION & $2.0939^{* *}$ & $0.8858^{* *}$ \\
& $(0.9577)$ & $(0.3565)$ \\
EXPERIENCE & 0.7389 & $-0.8083^{*}$ \\
& $(0.8170)$ & $(0.4336)$ \\
DEBT & -0.4348 & -0.0103 \\
& $(0.4648)$ & $(0.0752)$ \\
SIZE & 0.071 & -0.019 \\
& $(0.1493)$ & $(0.0192)$ \\
AGE & $-0.1197 *$ & $-0.0369^{*}$ \\
& $(0.0698)$ & $(0.0217)$ \\
CONSTANT & $0.0766^{* * *}$ & $0.0297^{* *}$ \\
& $(0.0197)$ & $(0.0126)$ \\
Industry-level Control & $-6.4035^{* * *}$ & 0.0822 \\
Cluster Standard Errors & $(1.6918)$ & $(0.8481)$ \\
AR(1) & Yes & Yes \\
AR(2) & Yes & Yes \\
Hansen & 0.0048 & 0.0153 \\
\hline \hline
\end{tabular}

Note: The coefficient values are stated in figures while the standard errors are stated in The figures of parentheses. ***, $* *$ and $*$ denotes the level of significances of $1 \%, 5 \%$ and $10 \%$ respectively.

\subsection{Robustness Test with different Maturity}

Our analysis shows that the specifications have one thing in common: the significant effect of age on firm performance. Therefore, we further test the effect of age of a firm on performance. We split the sample into Mature and Young firm. Those firms with age of establishment higher than the median of the average age in their industry were classified into Mature firms. Otherwise, those firms with age of establishment lower than the median of the average age in their industry were classified into Young firms. In the end, we have two sub samples, and we employ estimation model 
(2) and Model (3) for both sub samples. The model specifications were run under Panel GMM model,

Table 6 reports the results. For Mature firms, board capital has significant effect on firm performance. The coefficient values were 0.6161 and 0.2445 for ROA and Tobin's Q implying that higher board capital might induce the performance of mature firms. The findings are the same for Young firms, where board capital has positive effect on firm performance. Higher level of board capital will induce the performance of Young firms. The findings align with previous studies such as Muttakin et al (2018), Kontesa and Kyee (2019), and it is in-line with our previous results in Table 4.

However, those results cannot show which board capital dimensions affects the performance according to its age. We run again estimation model (3) to answer that intriguing issue. Table 6 shows two board capital dimensions have significant effects on the performance of Mature firms, namely, networking and experience. It surmises that higher networking level of board members in Mature firms will boost the performance. It also surmises that high experience board members in Mature firms will increase the performance. This is in line with $\mathrm{Su}$ et al (2016). Yet, education background of board members is not a significant factor for the performance of Mature firms. Meanwhile, only one board capital dimension has significant effect on the performance of Young firms, which is Networking. Education background and the experience of board members in Young firms are not a significant factor to induce the performance.

In a short, our research concludes two important findings. First, Young firms only have networking of board members as important factor to induce the performance. Meanwhile, Mature firms have networking and experience as the important factor to induce their performance. Hence, our results confirm prior studies such asSu et al (2016), Vandenbroucke et al (2016), Le and Kroll (2017), and Field and Mkrtchyan (2017). Lastly, education background of board members is not crucial for both Mature and Young firms' performance, which is in line with Serra et al (2016), Kagzi and Guha (2018), and Rossoni et al (2018).

Table 6: Sub-Sampling Results According to Age

\begin{tabular}{lcccccccc}
\hline & \multicolumn{3}{c}{ Mature } & \multicolumn{3}{c}{ Young } \\
\cline { 2 - 9 } & \multicolumn{2}{c}{ ROA } & \multicolumn{2}{c}{ Q } & \multicolumn{2}{c}{ ROA } & Q \\
\hline \multirow{2}{*}{ LAG(-1) } & $0.0413^{*}$ & $0.0410^{*}$ & 0.0587 & 0.0547 & $0.9284^{* * *}$ & $0.9276^{* * *}$ & -0.0069 & -0.0102 \\
& $(0.0245)$ & $(0.0231)$ & $(0.3270)$ & $(0.3253)$ & $(0.0937)$ & $(0.0944)$ & $(0.4092)$ & $(0.4078)$ \\
\hline \multirow{3}{*}{ BCAPITAL } & $0.6161^{* *}$ & & $0.2445^{* *}$ & & $0.5507^{* *}$ & & $0.3721^{* *}$ \\
\hline NETWORKIN & $(0.3088)$ & & $(0.1142)$ & & $(0.2560)$ & & $(0.1781)$ \\
G & & $1.3272^{* *}$ & & $0.2510^{* * *}$ & $0.7445^{* *}$ & $1.5495^{* *}$ \\
\hline & & $(0.6685)$ & & $(0.0761)$ & & $(0.3322)$ & $(0.7823)$ \\
EDUCATION & & 0.5465 & & -0.0773 & & 0.726 & & $-1.8575^{*}$ \\
& & $(0.5978)$ & & $(0.1161)$ & & $(0.9779)$ & $(1.0644)$ \\
EXPERIENCE & & $2.6939^{* * *}$ & & $0.0487 * *$ & & 0.2534 & 0.0636 \\
& & $(0.3712)$ & & $(0.0216)$ & & $(0.3962)$ & $(0.1810)$ \\
DEBT & -0.1458 & -0.1449 & 0.0086 & 0.0127 & $0.3908^{* *}$ & $0.3950^{* *}$ & -0.0402 & -0.0333 \\
& $(0.1756)$ & $(0.1718)$ & $(0.0104)$ & $(0.0100)$ & $(0.1825)$ & $(0.1818)$ & $(0.0266)$ & $(0.0271)$ \\
\hline
\end{tabular}




\begin{tabular}{|c|c|c|c|c|c|c|c|c|}
\hline \multirow{3}{*}{ SIZE } & \multicolumn{4}{|c|}{ Mature } & \multicolumn{4}{|c|}{ Young } \\
\hline & \multicolumn{2}{|c|}{ ROA } & \multicolumn{2}{|c|}{ Q } & \multicolumn{2}{|c|}{ ROA } & \multicolumn{2}{|c|}{ Q } \\
\hline & $\begin{array}{c}0.1086 \\
(0.0873)\end{array}$ & $\begin{array}{c}0.0371 \\
(0.1244)\end{array}$ & $\begin{array}{c}-0.0135^{* * *} \\
(0.0046)\end{array}$ & $\begin{array}{c}-0.0224 * * * \\
(0.0084)\end{array}$ & $\begin{array}{l}-0.0249 \\
(0.0771)\end{array}$ & $\begin{array}{l}-0.0151 \\
(0.0740)\end{array}$ & $\begin{array}{l}0.0301 \\
(0.0738)\end{array}$ & $\begin{array}{l}0.0331 \\
(0.0711)\end{array}$ \\
\hline CONS & $\begin{array}{c}5.8341 * * * \\
(1.1923) \\
\end{array}$ & $\begin{array}{c}4.2472 * * * \\
(1.2923) \\
\end{array}$ & $\begin{array}{c}-0.5354^{*} \\
(0.2901) \\
\end{array}$ & $\begin{array}{l}-0.4111 \\
(0.3839) \\
\end{array}$ & $\begin{array}{l}-1.5877 \\
(1.0242) \\
\end{array}$ & $\begin{array}{l}-1.6116 \\
(1.0577) \\
\end{array}$ & $\begin{array}{l}-0.2494 \\
(0.8127) \\
\end{array}$ & $\begin{array}{l}0.0601 \\
(2.2224) \\
\end{array}$ \\
\hline $\begin{array}{l}\text { Industry-level } \\
\text { Control }\end{array}$ & Yes & Yes & Yes & Yes & Yes & Yes & Yes & Yes \\
\hline $\begin{array}{l}\text { Cluster } \\
\text { Standard } \\
\text { Errors }\end{array}$ & Yes & Yes & Yes & Yes & Yes & Yes & Yes & Yes \\
\hline $\operatorname{AR}(1)$ & 0.0395 & 0.027 & 0.0325 & 0.0269 & 0.0339 & 0.0142 & 0.0339 & 0.012 \\
\hline $\operatorname{AR}(2)$ & 0.4312 & 0.2015 & 0.4441 & 0.2103 & 0.7262 & 0.3108 & 0.7202 & 0.3139 \\
\hline Hansen & 0.5464 & 0.0726 & 0.4752 & 0.685 & 0.1397 & 0.247 & 0.2644 & 0.3292 \\
\hline
\end{tabular}

\subsection{Discussion}

Board capital is empirically found to be positively influencing a firm's Return on Assets, but no effect on Tobin's Q. This indicates that the effect of networking, education, and experience varies to a firm's performance. For the accounting book performance such as ROA, those board capital dimensions have positive influences. There is also board capital effect on market-based performance such as Tobin's Q. The result is in line with our proposed theory which is resourcebased view theory and agency theory.

As addressed by Hillman et al (2009), Hillman and Dalziel (2013), Reeb and Zhao (2013), Muttakin et al (2018), and Kontesa and Kyee (2019) board capital is a competitive resource owned by a firm. This resource is not achieved by three or five years. It is earned as the working process of a director. This embedded resource is valuable and can be used by the director to enhance the firm's performance.

Knowledge transfer from board members to the organization is proven as an important process. It accelerates the competitive advantage of the firm due to additional resources from board members. Board members should have high human capital (networking, experience, and education) as that additional resource because it involves the process of embedded knowledge into the organization. If the board does not have enough capital, the knowledge that has transferred to subordinates will be insufficient to deal with the problem of the business especially during the economic downturn.

We further investigate the board's capital effects into more detail by dividing it into networking, education, and experience. The results report that networking has a significant influence on performance. It tells us that the board's networking backgrounds are significant factors to boost firm performance. Having a board member with a background of serving the government as an officer, having a political connection, or having good business networking will benefit the firm. Shareholders should consider this networking factor during the board member election. Because the higher the networking level of a board member, the better the performance will be. This 
conclusion is tally with prior knowledge such as Su et al (2016), Withers and Fitza (2017), and Wong and Hooy (2018).

Interestingly, education and experience are not a significant factor to induce firm performance. This means that no matter how good is the educational background of the board members, it will not give any impact on the performance. A firm that hired board members who graduated from Top University or had a Ph.D. degree will have no different effect from a firm that hired board members with a bachelor's degree in terms of the performance. In other words, shareholders can ignore educational background during board elections because education does not affect firm performance. Our argument is tally with prior findings such as Serra et al (2016), Kagzi and Guha (2018), and Rossoni et al (2018). They argue that knowledge from formal education might not be linear with the practical business world. Facing business challenges is not taught in formal education, therefore, having higher education may not assist the firm to induce their performance.

The same conclusion is also found in the experience dimension. Our findings show that the experience of board members has no significant effect on firm performance. This means that board members with higher experience cannot increase the performance of a firm. It tells us that shareholders can ignore the experience factor during board elections. This result is supported by Serra et al (2016) and Rossoni et al (2018), who argue that the current business cycle and trend are moving so fast. The experience in facing business turbulence in the 1990s might not be appropriate to be applied in the 2000s or even 2010s. During the 1990s, the competition is not that high compare nowadays, and the business chain has not yet disrupted by technology. Therefore, the experience is not necessarily to be a strategic resource for a firm.

Additionally, we add sensitivity analysis in our research as one control variable, which is Age, which shows a significant effect on performance. We split the sample into Mature and Young firms, and rerun the model. The results were quite surprising. First, Networking is indeed an important factor for both Mature Firms and Young Firms. It is not only well-established firms that need the networking of the board members to induce the performance, but also the newly established firms. Young firms may utilize networking to have a broader market for their suppliers and customers. Hence, it will help Young firms to boost their performance. In short, shareholders from both Mature and Young firms should consider board members' networking level during the annual general meeting in choosing the board.

Even though we did not find the significant role of experience in the full sample, the results of subsampling show that experience does matter for Mature firms, but not for Young Firms. Perhaps the economies of scale from Mature firms need more experience board members to competitively induce the performance. Mature firms relatively have a bigger and broader issue compared to Young firms. Therefore, experience board members are needed to sort out the problem faced by mature firms. Therefore, we can conclude that shareholders from Mature firms have to consider the experience level of a board member during the board election. However, Shareholders from Young firms can ignore the experience level until they reach the maturity cycle.

Lastly, our findings document that the educational background of a board member is still not a significant factor for the performance of Mature firms and Young firms. Having board members with the top-notch educational background may not give any impact on Mature firms, and it will 
also have no impact on Young firms. Therefore, shareholders from Mature firms and Young firms can ignore the educational background of a board member during the board election.

Additionally, our findings also support the agency theory from the perspective of alignment. A board member with higher capital might use it to achieve the firm's objective as part of their selfesteem and maintain their career in the firm. Moreover, the human capital theory explains higher capital board member tends to focus on recognition and self-actualization (Hillman et al, 2009, Muttakin et al, 2018). Therefore, they use their competitive resources such as networking, education, and experience for that matter.

\section{CONCLUSION AND IMPLICATION OF STUDY}

Our study contests the resource-based view and agency theory to explain the phenomenon of how director capital may boost firm performance. Our study is mainly motivated by the lack of attention given to these deserving emerging countries despite their unique research setting concerning the wide educational and organizational gap. This paper, by all means, lays the foundations for any further research in this topic on emerging markets with more focus on country-specific characteristics dimensions. In the end, our findings confirm resource-based view theory where board capital, specifically, networking capital, is a strategic resource for firms to induce their performance.

This paper uses the director capital measure developed by Reeb and Zhao (2013) with slight modifications in definitions. We also use two measures of performance which are market-based performance (Tobin's Q) and accounting-book performance (ROA). Our results documented a positive association between director capital and firm performance, and this brings implication about certain conceptualized frameworks and empirically evidenced for a new determinant of performance. Another contributing aspect of our study is that we use a panel data approach that allows for assessing changes in capital level albeit no significant changes in the capital levels over time and thus giving more reliable estimates. Further, we run panel GMM fixed effect to omit endogeneity, and control its error estimations to rectify any heteroscedasticity and serial correlation issues.

Our findings contribute to the industry by revealing the importance of board capital for firm performance. Shareholders have to consider networking capital during board elections for better firm performance. Meanwhile, education is not an important factor for firm performance where shareholders can ignore it during board elections. Additionally, shareholders of Mature firms should consider experience persons for their board members. In short, our findings surmise that even though board capital important for firm performance, yet, networking is the most important factor to induce firm performance.

However, all our findings need to be validated by further research on other countries, especially in emerging markets, to very some facts about certain common institutional background embedded in those markets. The focus of this study has been to examine the effect of board capital on firm performance. Yet, based on some of the common characteristics for developing markets, particularly for the South East Asian region, a few extensions can be further built upon this analysis. For example, more in-depth insights can be gained through an examination of the possible 
capital effect moderated by certain corporate governance variables. Some governance attributes such as board size, independent auditor, CEO duality, or the intervention effect of political settings or strategic change can be another interesting extension of study for this analysis.

\section{REFERENCE}

Bandyopadhyay, A., \& Barua, N. M. (2016). Factors determining capital structure and corporate performance in India: Studying the business cycle effects. The Quarterly Review of Economics and Finance, 61, 160-172.

Becker, G. S. (1964). Human capital theory. Columbia, New York.

Brahmana, R., Ung, L. J., \& Kiu, J. S. (2019). Does board capital affect the corporate financial distress level? A study from Malaysia. Kasetsart Journal of Social Sciences, 40(3), 695702.

Cao, Y., Myers, J. N., Myers, L. A., \& Omer, T. C. (2015). Company reputation and the cost of equity capital. Review of Accounting Studies, 20(1), 42-81.

Claessens, S., Djankov, S., Fan, J. P., \& Lang, L. H. (2002). Disentangling the incentive and entrenchment effects of large shareholdings. The Journal of Finance, 57(6), 2741-2771.

DeFond, M. L., Hann, R. N., \& Hu, X. (2005). Does the market value financial expertise on audit committees of boards of directors?. Journal of Accounting Research, 43(2), 153-193.

Demerjian, P. R., Lev, B., Lewis, M. F., \& McVay, S. E. (2013). Managerial ability and earnings quality. The Accounting Review, 88(2), 463-498.

Field, L. C., \& Mkrtchyan, A. (2017). The effect of director experience on acquisition performance. Journal of Financial Economics, 123(3), 488-511.

Gregg, F. (2006). Inherited control and firm performance. The American Economic Review, 96(5), 1559-1588.

Hall, M., \& Weiss, L. (1967). Firm size and profitability. The Review of Economics and Statistics, 319-331.

Haynes, K. T., \& Hillman, A. (2010). The effect of board capital and CEO power on strategic change. Strategic Management Journal, 31(11), 1145-1163.

Hillman, A. J., \& Dalziel, T. (2003). Boards of directors and firm performance: Integrating agency and resource dependence perspectives. Academy of Management review, 28(3), 383-396.

Hillman, A. J., Withers, M. C., \& Collins, B. J. (2009). Resource dependence theory: A review. Journal of management, 35(6), 1404-1427.

Hribar, P., \& Craig Nichols, D. (2007). The use of unsigned earnings quality measures in tests of earnings management. Journal of Accounting Research, 45(5), 1017-1053.

Iskandar, T., Noor, Z., \& Omar, N. (2012). Characteristics of board of directors and financial distress: A Malaysian case. Jurnal Pengurusan, 36, 77-88.

Kagzi, M., \&Guha, M. (2018). Does board demographic diversity influence firm performance? Evidence from Indian-knowledge intensive firms. Benchmarking: An International Journal, 25(3), 1028-1058.

Karamanou, I., \&Vafeas, N. (2005). The association between corporate boards, audit committees, and management earnings forecasts: An empirical analysis. Journal of Accounting Research, 43(3), 453-486.

Khatri, N., \& Ng, H. A. (2000). The role of intuition in strategic decision making. Human Relations, 53(1), 57-86. 
Kontesa, M., \& Kyee, S. B. (2019). Role of board capital on bank efficiency. Jurnal Akuntansidan Bisnis, 18(2), 164-177

Lang, G. E., \& Lang, K. (1988). Recognition and renown: The survival of artistic reputation. American Journal of Sociology, 94(1), 79-109.

Le, S., \& Kroll, M. (2017). CEO international experience: Effects on strategic change and firm performance. Journal of International Business Studies, 48(5), 573-595

Leuz, C., \& Oberholzer-Gee, F. (2006). Political relationships, global financing, and corporate transparency: Evidence from Indonesia. Journal of financial economics, 81(2), 411-439.

Morresi, O. (2017). How much is CEO education worth to a firm? Evidence from European firms. PSL Quarterly Review, 70(282), 311-353.

Muttakin, M. B., Khan, A., \& Mihret, D. G. (2018). The effect of board capital and CEO power on corporate social responsibility disclosures. Journal of Business Ethics, 150(1), 41-56.

Reeb, D. M., \& Zhao, W. (2013). Director capital and corporate disclosure quality. Journal of Accounting and Public Policy, 32(4), 191-212.

Rose, C. (2007). Does female board representation influence firm performance? The Danish evidence. Corporate Governance: An International Review, 15(2), 404-413.

Rossoni, L., Aranha, C. E., \& Mendes-Da-Silva, W. (2018). Does the capital of social capital matter? Relational resources of the board and the performance of Brazilian companies. Journal of Management \& Governance, 22(1), 153-185.

Serra, F. R., Tres, G., \& Ferreira, M. P. (2016). The 'CEO' effect on the performance of Brazilian companies: An empirical study using measurable characteristics. European Management Review, 13(3), 193-205.

Sheng, S., Zhou, K. Z., \& Li, J. J. (2011). The effects of business and political ties on firm performance: Evidence from China. Journal of Marketing, 75(1), 1-15

Thornhill, S., \& Amit, R. (2003). Learning about failure: Bankruptcy, firm age, and the resourcebased view. Organization science, 14(5), 497-509.

Ung, L. J., Brahmana, R., \& Puah, C. H. (2016). Does retrenchment strategy induce family firm's value? A study from Malaysia. International Journal of Management Practice, 9(4), 394411.

Vandenbroucke, E., Knockaert, M., \& Ucbasaran, D. (2016). Outside board human capital and early stage high-tech firm performance. Entrepreneurship Theory and Practice, 40(4), 759-779.

Withers, M. C., \& Fitza, M. A. (2017). Do board chairs matter? The influence of board chairs on firm performance. Strategic Management Journal, 38(6), 1343-1355.

Wong, W. Y., \& Hooy, C. W. (2018). Do types of political connection affect firm performance differently?. Pacific-Basin Finance Journal, 51, 297-317. 